\title{
The Issue of Genealogy of Armenians, Georgians and Other Caucasian Nations in the Historiography of the Middle Ages
}

\author{
Manana Sanadze \\ The University of Georgia, Georgia, Tbilisi
}

\begin{abstract}
The paper shows that the story about the origin of Armenians, Georgians and other Caucasians from a common ancestor, namely, from Targamos (Togormah)—The Life of the Fore-Patriarchs and Ancestors of the Georgian Kings, which is represented in the introductory part of The Georgian Chronicles and is dated back to the end of the $11^{\text {th }}$, is a compiled work that mainly contains, on the one hand, an old Georgian genealogical-geographical story about Tarshish's son Kartlos (Iber) and his six brothers ( Egros, Movakan, Heros, Bardos, Lekan and Caucas) created at the end of the $6^{\text {th }}$ c.-first half of the $8^{\text {th }} \mathrm{c}$. based on Byzantine works, and on the other hand, a genealogical story created in old Armenian historiography about Targamos and his son Hayk that went through certain steps of development as well. In the process of synthesizing, Togormah (Targamos) and his son Hayk (Haos) were inserted between Tarsish and his son Kartlos (Iber), which violated the Biblical scheme as well as the structure of the sentence in which the insertion was made. The goal of developing the synthesized scheme was to bring evidence of the common origin of Georgians and Armenians, as long as quite a large number of Armenians, because of the incorporation of a large part of Armenian territories within Georgian borders, became citizens of Georgia. At the same time, the story also offers a justification in the eyes of the Muslim world for the claims of Georgia for Armenian territories. According to the newly-created synthesized scheme, Georgia was "the successor brother" of Armenia (Haos//Hayk) and considering the absence of Armenian states, i.e., "the elder brother", Georgia was the only legal heir of Armenian territories.
\end{abstract}

Keywords: Georgians, Armenians, Caucasians, Middle Ages, genealogy

\section{Introduction}

Traditional attitude towards the introductory part of The Georgian Chronicles-The Life of the Fore-Patriarchs and Ancestors of the Georgian Kings, which narrates the arrival of the legendary ancestors of Georgian kings (the forefathers) in South Caucasia and their settlement there, has been quite critical in Georgian historiography. It was considered that the story has no scientific value whatsoever and that it is just an unrealistic attempt to develop a version of the origin of Georgians suited to the biblical scheme. Researching the issue has shown that the story is interesting in many regards. First of all, the research unveiled the source of the story, which turned out to be a tale about Kartlos and his six brothers. This tale, along with an Armenian genealogical work, makes the core of The Life of the Fore-Patriarchs and Ancestors of the Georgian Kings. It also appeared that this introductory part of The Georgian Chronicles, presumably created and compiled by Leonti Mroveli - bishop of the Ruisi Eparchy in the $2^{\text {nd }}$ half of the $11^{\text {th }}$ c., had very specific geo-political aims

Manana Sanadze, Doctor of Historical Sciences, Full Professor, The University of Georgia. 
and reflected the aspirations of the Georgian society of the $11^{\text {th }}-12^{\text {th }}$ cc., to liberate territories populated with Christian Armenians from Muslims and to incorporate them within Georgian borders.

\section{The Place of Armenians and Eastern Georgians (Iberians) in Byzantine Genealogical Schemes}

After conversion to Christianity, Christian scholars of the Eastern Roman Empire (Byzantium) associated characters of local and foreign historical epos, including those of Persian, Georgian and Armenian origin, with Biblical ones. Thus, scholars associated nations with Biblical ancestors and included them in genealogic "books" based on the Bible. From Byzantine writings these genealogies were mastered by Georgian and Armenian historians as well. Finally, the introductory part of The Georgian Chronicles-The Life of the Fore-Patriarchs and Ancestors of the Georgian King, compiled the Byzantine, Armenian and Georgian versions of the ethnic origins of peoples and turned them into an orderly arranged genealogic scheme of the origin and kinship of Georgian, Armenian and in general Caucasian nations (Sanadze \& Arakhamia, 2012, pp. 258-280; Sanadze, 2016, pp. 41-80).

This story "The Life of the Fore-Patriarchs and Ancestors of the Georgian King" was created as a result of synthesizing previous separately existing versions about the descent of Armenianson on one hand and Kartlos i.e. Iber (the fore-father of Eastern Georgians) and his six brothers on the other hand, first narrates the settlement of Caucasia by the Biblical fore-father Targamos (Togarmah), whom the chronicler presents as "the son of Tarsh[ish], the grandson of Japheth". Then the narrative continues with the story of the descendants of Targamos-Targamosids, their battle with Nimrod and his defeat. Targamosids are assumed to be the ancestors of Armenians, Georgians (Eastern and Western), North Caucasians and Caucasian Albanians ${ }^{1}$.

In the $19^{\text {th }}-20^{\text {th }}$ centuries, when Georgian historians started the critical analysis of The Georgian Chronicles, this introductory part of The Chronicles was declared as completely devoid of historical events and considered to be a representation of a Biblical scheme. Actually, this is a case of representing historical information from a Biblical perspective by historians of the Middle Ages. Targamos is Togarmah, the grandson of the Biblical character Japheth ${ }^{2}$ the son of Noah. His name is mentioned in the part of the Bible called "Genesis".

The Georgian chronicler states the following: “Armenians, Kartvels, Rans, Movakans, Hers, Leks, Megrels and Caucasians had a common father, named Targamos. This Targamos was the son of Tarsh[ish] and the grandson of Japheth the son of Noah" (The Georgian Chronicles, 1955, p. 3). As we can see, the chronicler presents the genealogy of Caucasian nations. What is it based on?

After the spread of Christianity, Christian people of Europe and the Near East started to relate their mythical stories of their origin and written legends to the Bible and defined them based on the Biblical genealogical scheme. Since according to the Bible only Noah survived the Great Deluge, consequently, in the writings of Christian scholars, all the nations originated from the three sons of Noah's-Shem, Ham and Japheth.

\footnotetext{
${ }^{1}$ Albanians are one of the ancestors of contemporary Azeris. The population of modern Azerbaijan originated from tribes of Caucasian origin (Caucasian Albanians) which had assimilated with Turkish, Iranian and some Arabic tribes. In the process of assimilation, the Turkish language turned out the prevailing one. As for the ethnotype, the Caucasian one appeared stronger. The religion and culture bear signs of considerable Iranian influence. The Caucasian ethnotype can well be observed in the appearance of the Azeri population. It is clear that the Turkish speaking nations living east of the Caspian Sea: Kazakhs, Uzbeks, Turkmens are Mongoloids, while Azeris bear obvious visual resemblance to Georgians and other Caucasian nations. The same can be said about the population of Turkey, where Mongoloid traits have been lost due to assimilation with Greeks, Georgians, Armenians and other nations of Asia Minor.

${ }^{2}$ According to the Bible, Togarmah is the son of Gomer, the son of Japheth.
} 
It is important to consider that belonging to one of Noah's sons was based not on an ethno-genetic principle at all, but the territorial one: the nations of contemporary Europe, Russia, Caucasia and the largest part of West Asia were assumed to be the descendants of Japheth, nations in the south and southeast of Asia were considered to be the descendants of Shem, while the nations of Africa (Libya) India, China-of Hem. It has to be acknowledged that there was no specific firmly established knowledge on the issue. This is evidenced by the fact that some nations were listed among Japheth's descendants by one author, and referred to as the descendants of Shem or Hem on the lists of others, or in other passages of the same authors' works. This can be explained by a wide range of sources used by Christian scholars of the Middle Ages while writing their works, which were compilations of various sources. This is how "Books on the Origin of Nations", greatly differing from one another in terms of the classification of nations and their geographical distribution, were created. Across centuries, many versions of such "books" were written and ethno-political changes of the periods were reflected in them.

Since converting to Christianity and getting to know Byzantine writing closely, the interest of Georgian society in their origin increased significantly. To satisfy this curiosity, historians naturally referred to Byzantine writings and started developing their own genealogical scheme. That's why we should be interested in what idea was common in the Byzantine genealogical works.

In Chronography written by George Syncellus (VIII - IX cc) it is mentioned that Iberians along with Caucasian Albanians, Colchis, Chalybes, Mossynoeci and Armenians are Japheth's descendants. Besides, Syncellus presents a more specific genealogy of Armenians and Iberians:

E. g.
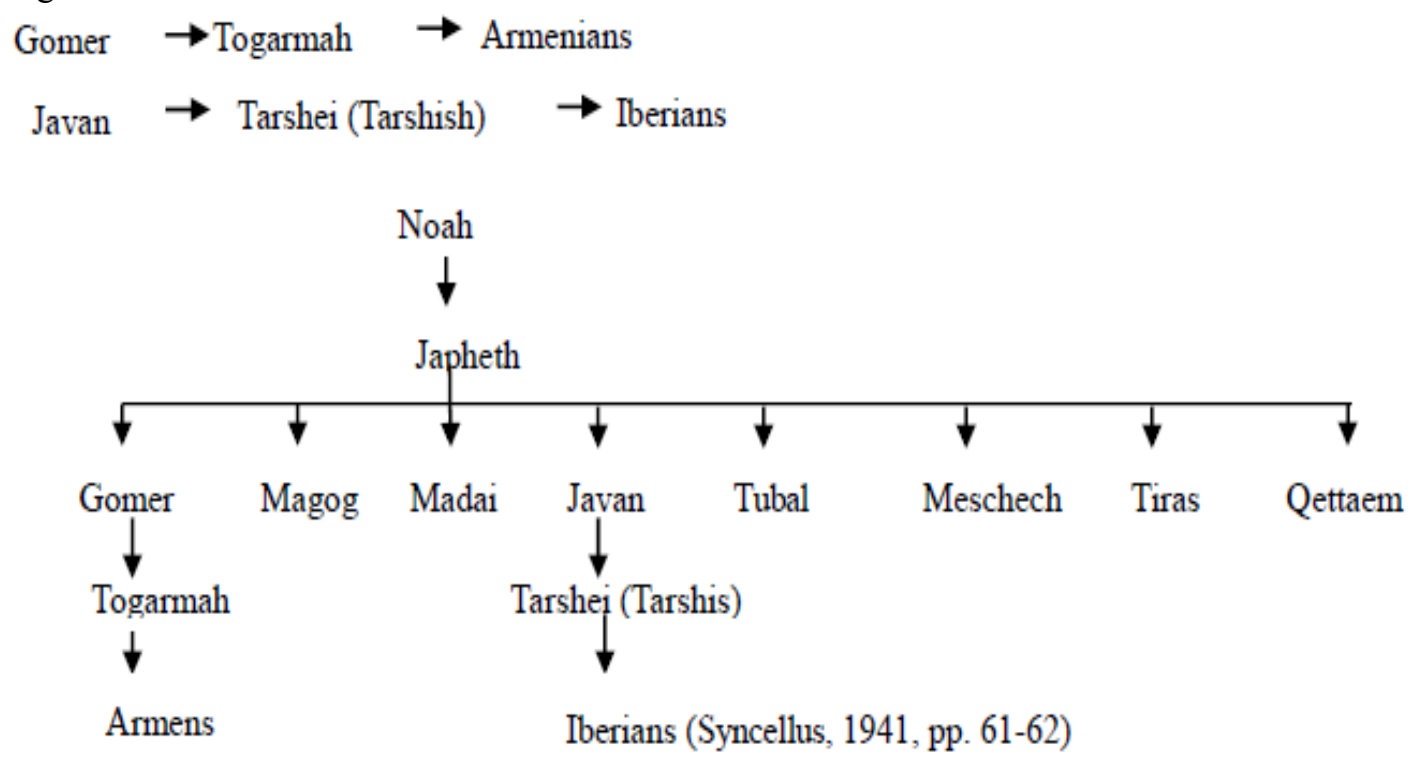

In this case, the scholar was not creative at all. In Byzantine historiography there were works written long before George Syncellus, which preserved the same information. One of the examples is a text of Hippolytus of Rome, according to which Armens (Armenians) are descendants of Togarmah and Iberians originate from Tarshish (Kekelidze, 1955, p. 100). In the Armenian version of the same chronicle, the ethnarch of Armenia is Togarmah and that of Georgians (Eastern Georgians, i. e. Iberians)—Tarshish (Abdaladze, 1982, p. 100). 
The same evidence is presented in a Latin text Liber Generationis ${ }^{3}$ in which, after the list of the names of Japheth's sons ${ }^{4}$, the sons of Gomer the son of Japheth are named: Askanat, Riphat and Togarmah, while Armenians are considered to be Togarmah's descendants. At the same time, the author of the text lists the names of Javan's sons: Elishah, Tarshish, Kit (Kittim in the Bible), Rhodes (Dodanim) and identifies Iberians as descendants of Javan's son Tarshish (Tarsei). Thus, the text Liber Generationis suggests the following genealogical tree for Armenians and Iberians:

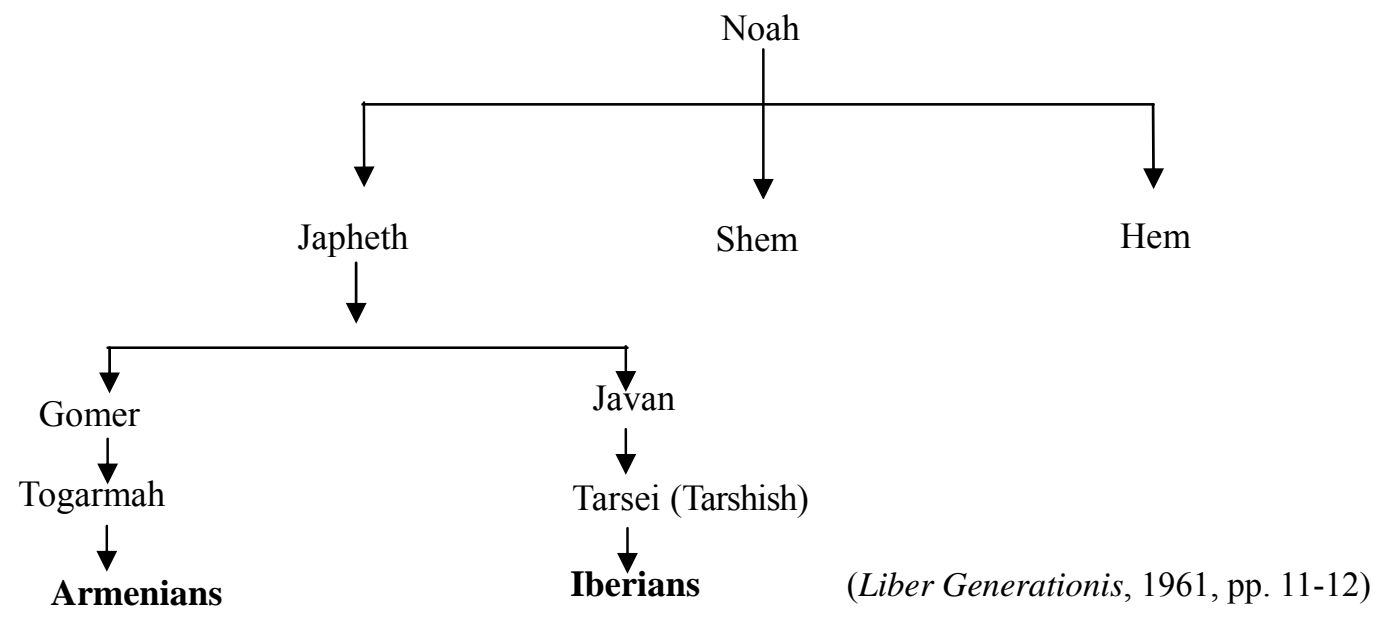

\section{The Armenian Genealogical Scheme and Stages of Its Development}

It is obvious that Georgian and Armenian educated society absorbed genealogical information from Byzantine sources quite early. However, at the same time, before the above-mentioned Greek historiography was introduced in Armenia or due to the influence of some Byzantine author whose identity is unknown to us, or due to a rewriter's and translator's negligence, a genealogical tree that differs from the Bible itself and Byzantine authors mentioned above was established in Armenia. This genealogical scheme has been preserved in the very beginning of Movses Kaghankatvatsi's work The History of the Country of Alvans which, considered Togarmah (the ancestor of the Armenians' ethnarch-Hayk) to be the grandson of Japheth, yet considered him to be the son of Tiras and not of Gomer as it is in the Bible. In the same way, Biblical brothers of Togarmah, Askhenaz and Riphat were presented as the sons of Tiras. As for Movses Kaghankatvatsi's information about the origin of Georgians, specifically, Eastern Georgians (Iberians, in Armenian-"Virk") it accurately reaffirms the information preserved in Liber Generationis and Chronography of George Syncellus that we have already analyzed above.

Movses Kaghankatvatsi's origin from Ran, the fact that Ran was the name of Caucasian Albania, situated on the right bank of the Mtkvari, and the period of Movses' life (the second half of the $7^{\text {th }}$ century, as it is considered today) provide grounds to assume that information preserved in his works was well-known and popular among the Georgian society of that period. The genealogical scheme of the origin of Armenians and Eastern Georgians ("Virk") presented by Movses Kaghankatvatsi is as follows:

\footnotetext{
3 The first version of the text dates back to the 3rd century, though it was edited several times in the following centuries.

${ }^{4}$ Gomer, Magog, Madai, Javan, Elisa, Tubal, Mosoch (Meschech), Tiras, Coratis.
} 
Scheme №1

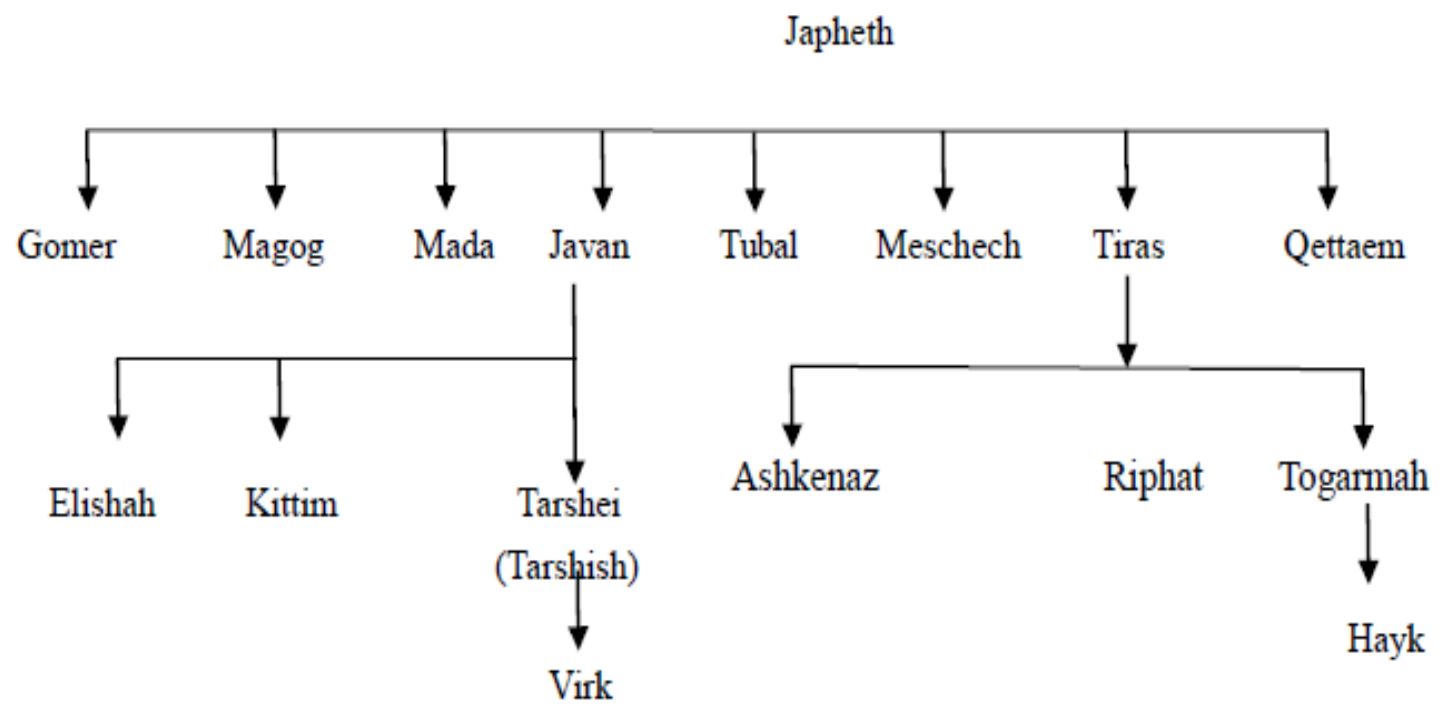

(Kaghankatvatsi, 1985, pp. 23-24)

The following information regarding the origin of Armenians had reached Movses Khorenatsi (more specifically, the editor-extender of his texts) in the condition as follows: (1) The information about Hayk's origin from Togarmah and the descent of the latter from Tiras, the son of Japheth, was wide-spread in Armenia, which, as we saw above, can be noticed in the very beginning of Movses Kaghankatvatsi's work The History of the Country of Alvans; (2) similar to the Bible, in Byzantine Liber Generationis, Gomer, the son of Japheth was considered to be the father of Togarmah. This differed from the scheme established in Armenian society, which narrated the descent of Togarmah and his brothers (Askenaz, Rifat) from another son of Japheth-Tiras. In these conditions Movses Khorenatsi's editor-extender followed the logic that would be typical of a historian of the Middle Ages. He tried not to lose any piece of information and directly compiled the seemingly contradictory viewpoints into one scheme.

According to this edited scheme, the Armenian's ethnarch Hayk, the son of Togarmah, leaves Babylon together with his sons Aramenyak (Armen), Manavaz, Khoro and grandsons-Kadmos, Baza and seven daughters with their husbands and children. They head towards the Armenian territory (near Van Lake in the Hark province and towards the north to the basin of the Araxes River) and settle there. As a result of compilation and synthesis of Armenian and Byzantine views and sources, Hayk's genealogy is represented the following way in the text produced by Movses Khorenatsi (or his editor-extender): 


\section{Scheme №2}

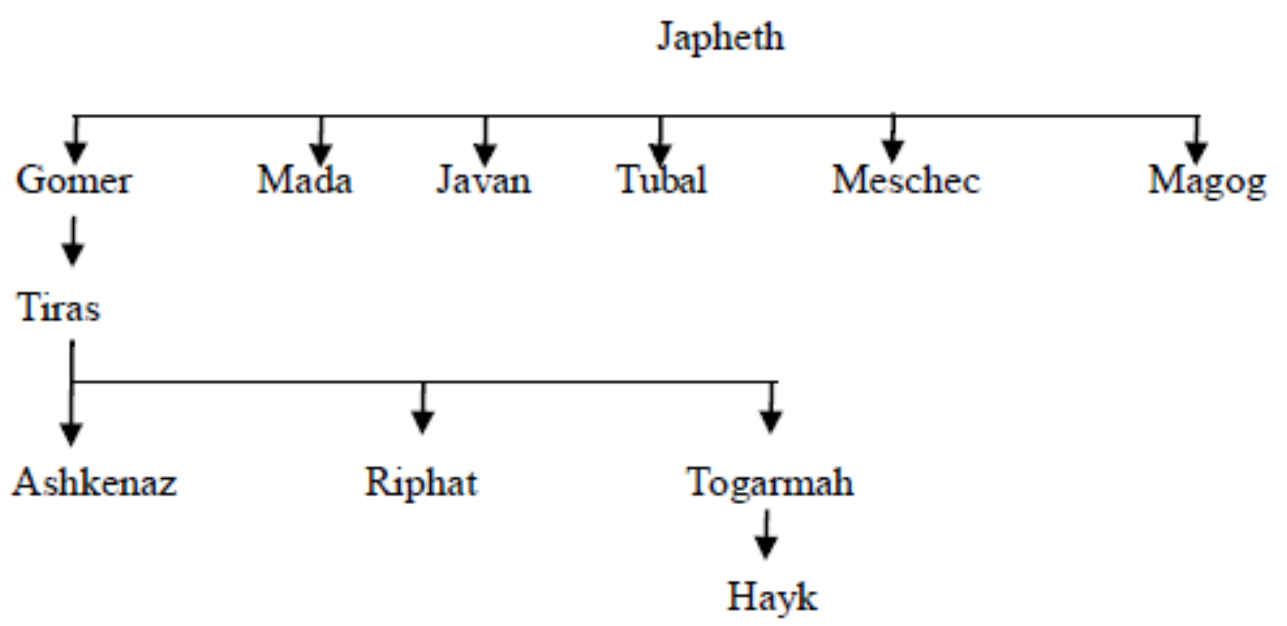

(Khorenatsi, 1984, pp. 62, 69, 75)

Thus, Movses Khorenatsi's editor-extender managed to maintain neutrality-he took into consideration the tradition spread in Armenia, the version of Byzantine authors and the one from the Bible at the same time; he placed Tiras between Gomer and Togarmah and turned him from Gomer's brother into the son of Gomer. This way, Togarmah remained Tiras' son, though Gomer became his grandfather. Through this, the Armenian version got closer to the Byzantine and Biblical versions as much as it was possible. This converged version of the origin was further widely accepted in Armenian historiography and recognized as a historical fact.

It is interesting that in later centuries (presumably in the $10^{\text {th }}$ century) the extender of Movses Kaghankatvatsi suggested Movses Khorenatsi's version of genealogy and did not even notice that his predecessor had a different viewpoint just a few pages before. The editor-extender of Movses Kaghankatvatsi represented the following genealogical scheme:

Japheth $\rightarrow$ Gomer $\rightarrow$ Tiras $\rightarrow$ Togarmah

(Kaghankatvatsi, 1985, p. 39)

\section{Caucasian Nations in Arabic Genealogical Works}

When Arabs appeared as prominent actors in history, their interest in the translation and distribution of Roman-Byzantine literature on the origin of nations increased greatly as well. The period between the $7^{\text {th }}$ and $9^{\text {th }}$ centuries is marked by the production of genealogical literature of various types which represented the origin of Arab tribes as well as the origin of conquered nations including South Caucasian nations and other well-known cities and countries. In his work Arab Historiography and Concept of Nations Origins, G. Japaridze analyzes genealogical schemes of Arab authors writing about South Caucasia over several centuries $\left(9^{\text {th }}-15^{\text {th }}\right.$ centuries) and notes that they are based on both Biblical-Byzantine and Arab-Islamic literature and tradition (including the Quran, hadiths, legends stemming from the common Semite and Iranian mythology) and information that Arabs get from South Caucasian nations as well (Japaridze, 2009, p. 202). 
It has to be mentioned that similar to Byzantine sources Arab ones mainly identify Eastern Georgians (Jurjan in Arabic), Albania of the right bank of the Mtkvari-Ran (in Arabic-Arran) - the country of Bardos according to The Georgian Chronicles and Armenia (in Arabic-Armina) with Japheth's (in Arabic-Japes) descendants.

Among Arab authors, the earliest suggestion of close kinship of Georgians (Gurzan), Armenians (Armina) and Albanians of the right bank of the Mtkvari River-Ran(Arran) and their origin from Japheth belongs to historians and geographers - the son and the father-Al-Qalbs: Muhamed Ibn Al-Sa'ib al-Qalb ( ${ }^{\text {th }}$ century) and Abu 1-Munzir Hisyam Ibn Muhammad Ibn Al-Sa'ib Al-Qalb (837-921). It is worth mentioning that their notes on this issue have not survived in a form of primary sources. Instead, their writings have been preserved through later authors: Yakut Ibn Abd Allah Al-Hamav Ar-Rum (died in 1229) and Shams Ud-din Muhammad Ibn Abi Talib Ad-Dimashki (died in 1327). In the genealogy of the father and son-Al-Qalbs, if we believe Yakut and Shams Ud-din, from one side Rhum, Armina Sakaliba and Apranji are presented as Togarmah's children; from the other side Jurzan and Arran are presented as Togarmah's children as well. Their unified genealogical scheme can be shown in the following way:

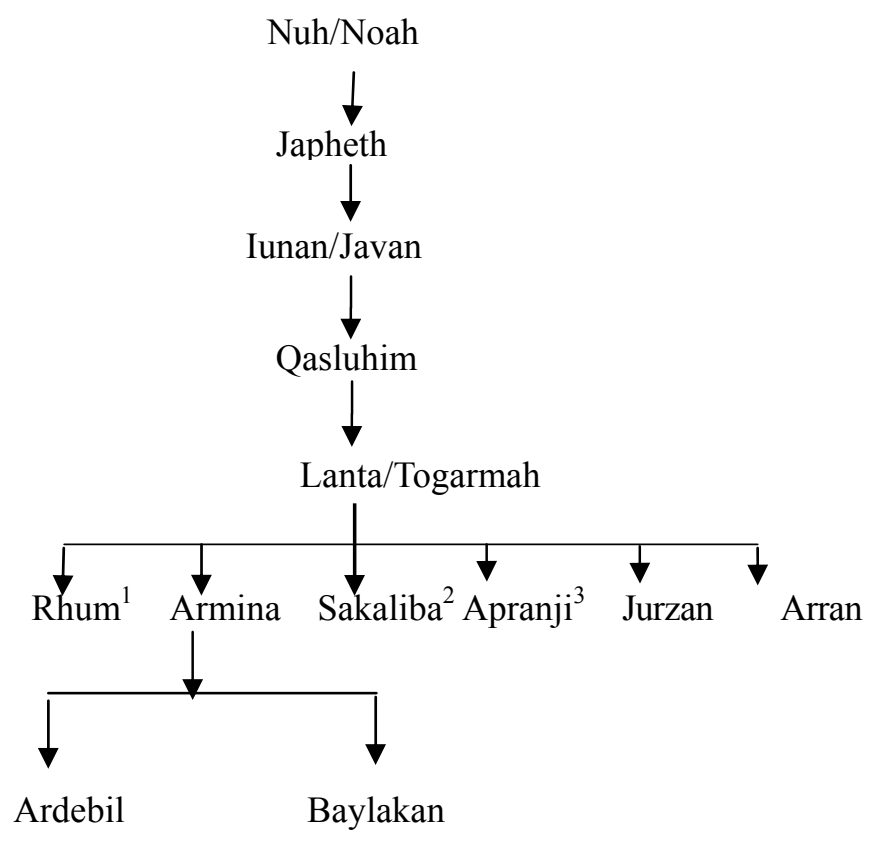

${ }^{\mathbf{1}}$ Byzantine, ${ }^{2}$ Slavs, ${ }^{3}$ Branji - French People.

Yakut amends this genealogical scheme and shows that "Lanta" (Togarmah) is Avmar's (Gomer) and not Qasluhim's son. As a result of this correction, the origin of Armenians (Armina) in Yakut's text is of the following type: 


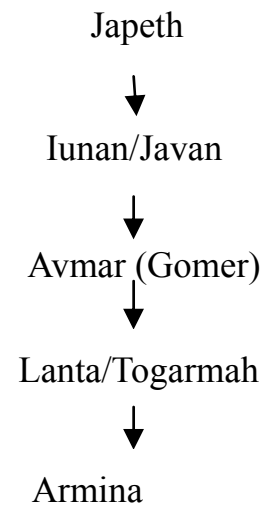

(Japaridze, 2009, pp. 200, 203)

More precisely, Shams Ud-din Ad-Dimashki's genealogy ${ }^{5}$ looks as follows:

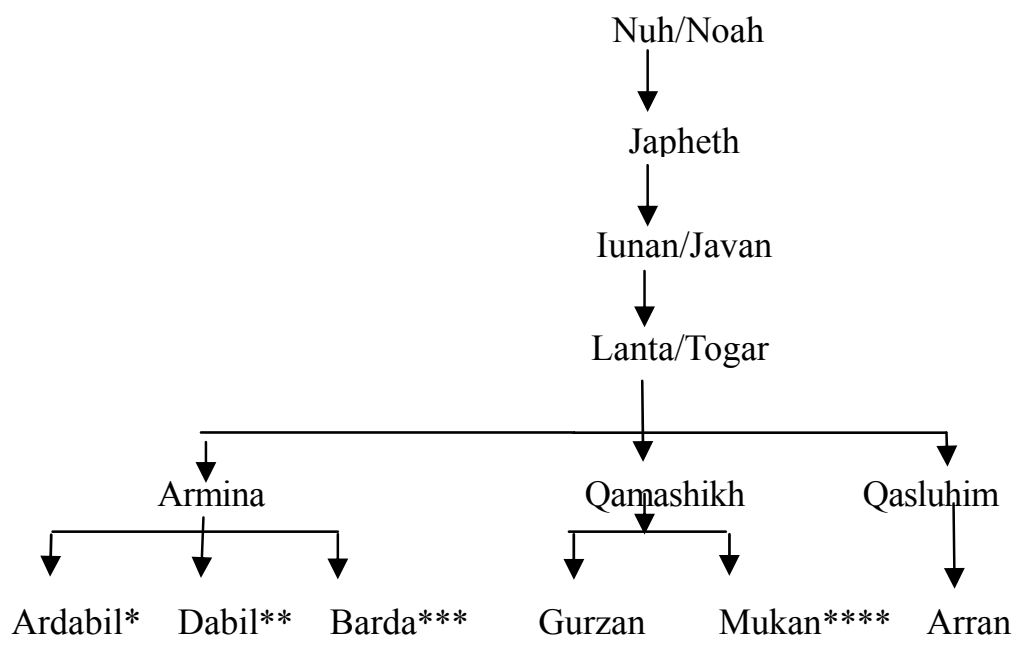

* In the respective part of his work G. Japaridze uses Dabil (i.e. Dvin) for the second time, which should be an unintentional mistake made in the process of rewriting. In reality, it should be assumed that Ardebil was the correct form that had to be written in the text. That is why we restore Ardebil as the correct version.

** Dvin

*** Bardav

****Mtkvari River right side Albania.

What is the basis of the genealogy of these Arab authors? An answer to this question may be unequivocal: (1) this is a work of Christian-Byzantine genealogic literature, (2) renewed versions of literary sources were transformed into oral folk stories by Caucasian people, and what is the most noticeable (3) the geo-political conditions in South Caucasia of that time. In this regard, it is interesting to note that Ad- Dimashki's genealogy is more archaic. He mentions Mukan and Barda (Movakan and Bardos, according to The Georgian Chronicles), whereas, in other cases we have Ardebil and Baylakan. It's also obvious that in this case not the ethno-genetic principle is taken as the basis of brotherhood but the geo-political condition and they have been named, having equal status political associations, according to their central fortress cities.

\footnotetext{
5 According to G. Japaridze, Ad-Dimashki offers us his own genealogy which somehow changed Al-Qalb's genealogy. Although he does not mention him, the basis of his initial genealogy is still Abu l-Munzir Al-Qalb's genealogy.
} 


\section{Forming the Georgian-Armenian Synthesized Scheme}

As it becomes clear from Movses Kaghankatvatsi's scheme \#1, in the same period (in the $6^{\text {th }}-7^{\text {th }} \mathrm{cc}$.) under the influence of Byzantine writings, Georgians (Eastern Georgians-Iberians-Virk) also found their ancestors among Japheth's sons and grandsons:

Japheth $\rightarrow$ Javan $\rightarrow$ Tarshish $\rightarrow$ Virk $\quad$ (the same Iber-Kartlos in the Georgian translation)

Unlike Armenian historiography, Georgian historians have represented the genealogy of Georgians (Eastern Georgians) in the context of brothers.

Let us go back again to the text of The Life of the Fore-Patriarchs and Ancestors of the Georgian Kings which is the product of the end of the $11^{\text {th }}, 1^{\text {st }}$ half of the $12^{\text {th }}$ century in this form. The historian states that: Togarmah was the father: "of Armenians, Kartvels ${ }^{6}$, Rans, Movakans, Hers, Leks, Megrels and Caucasians. Togarmah was the son of Tarshish and the grandson of Japheth the son of Noah" (The Georgian Chronicles, 1955, p. 3).

Thus, The Life of the Fore-Patriarchs and Ancestors of the Georgian Kings provides the following genealogy:

Noah $\rightarrow$ Japhet $\rightarrow$ Tarshish (Tarsei) $\rightarrow$ Togarmah

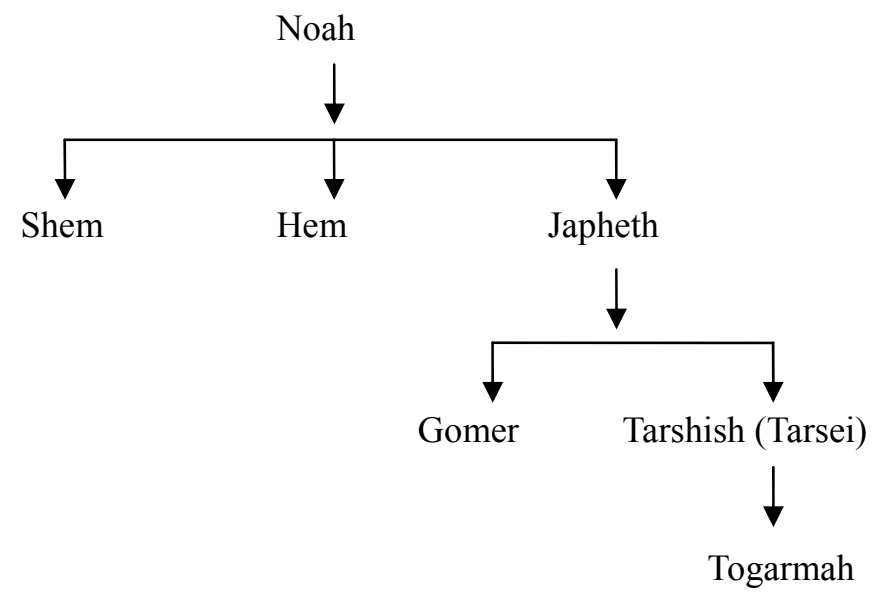

If we closely look at the internal structure of this sentence from The Georgian Chronicles, we will see that it had to be built according to the principle of defining the predecessor: e.g. Togarmah is defined as Tarsei's son; Japheth is named as Noah's son and Tarsei's father is not named anywhere, whereas the author gives two implications about Togarmah: first, he, by error, says that Togarmah was Tarsei's son; second, he says that Togarmah was Japheth's grandson. Togormah really is the grandson of Japheth, but in this case, he is the son of Gomer, and not of Tarshish (Tarsei), who was the grandson of Japheth as well. Everything will be in its own place if we take out Togormah and his son Haik//Haos as a later insertion in frames of synthesizing two, Armenian and Georgian genealogical schemes. In such a case the genealogical story about Kartlos (Iber/Virk) and his six brothers and the validity of the sentence will be restored in his initial stage: "Kartvels, Rans, Movakans, Hers,

${ }^{6}$ Here, meaning Eastern Georgians. 
Leks, Megrels and Caucasians had a common father, named Tarsh[ish]. Tarsh[ish] was the grandson of Japheth, the son of Noah".

It becomes clear that the Georgian historian chose the following way of synthesizing the schemes: he took out Togarmah and his son Hayk (Haos) from the Armenian scheme, and put them between Tarshish and Kartlos (Iber/Virk). As a result of such a mechanical insertion, the sentence defining Tarshish in the primary Georgian genealogical scheme: "Tarshish was the grandson of Japheth, son of Noah" turned into the sentence defining Togarmah: "This Togarmah was the son of Tarshish and the grandson of Japheth, theson of Noah".

This way, it turned out that the information that previously corresponded to Tarshish in the text: "the grandson of Japheth, the son of Noah", was now used to describe Togarmah. However, if such a definition was correct in the first case (Tarshish, according to the Bible, was really the grandson of Japheth, the son of Noah), under the new circumstances, it turned out a mistake with regard to Togarmah. The fact that the text was edited in exactly the way described can be proven by that: Tarshish, as we mentioned above, in the new synthesized scheme was left without any definition at all. Finally, the synthesized version of the Georgian-Armenian genealogical schemes offered by the chronicler, took the following form:

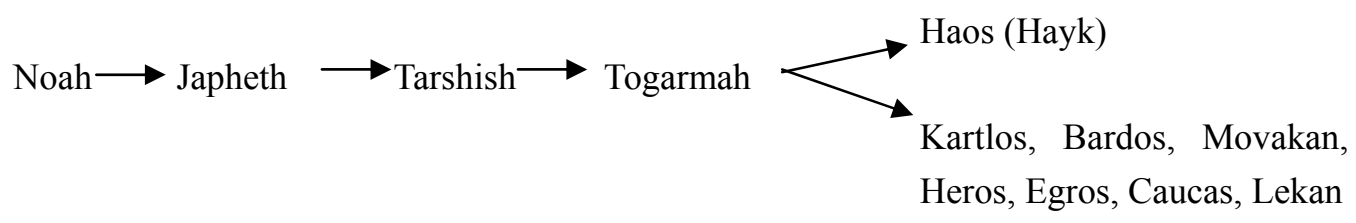

If we take a closer look at the synthesized genealogical scheme, it becomes evident that it represents a compilation of the genealogical schemes of Togarmah's son Haos and Tarsei's sons: Kartlos and his six brothers-Bardos, Movakan, Heros, Egros, Caucas and Lekan. Thus, there was a separate "story" of Tarsei's sons-Kartlos and his six brothers' genealogy (i.e. the genealogy of seven brothers) which, as we will see below, was a short genealogical story of a geopolitical character written no earlier than the end of the $6^{\text {th }}$ century and no later than the $1^{\text {st }}$ half of the $8^{\text {th }}$ century.

Now we will dwell on the ancient Georgian version, where Kartlos, Ergos, Lekan, Movakan, Bardos, Heros and Caucas were presented as brothers. We must note that as the research conducted specifically in this direction has revealed, the brotherhood here does not include the ethno-genetic factor: by that time, it was impossible to identify it on the linguistic, even more so on the genetic level. In this regard, the fairly detailed outline of the area helps the researchers, which was allegedly inherited by each brother from their father. By moving this draft to the map, it becomes clear that the basis of the brotherhood is the equal political status of Kartli, as a political entity, with respect to its neighbouring units, which means that these political units are not the vassals of Kartli (in this case they would be sons). Just as none is the suzerain of Kartli, in this case they would be fathers (Sanadze \& Beradze, 1999, pp. 100-112).

After this, the chronicler outlines the children of Kartlos, i.e., Kartli as a country-Kakhos, Kukhos, Gardabos, Gachios and Mtskhetos. In this case, "children" are the large feudal domains within the Kingdom of Kartli (or within the patriciate of Kartli): Kakheti, Kukheti, Gachiani, Gardabani and Mtskheta. The fact that Mtskheta includes the united feudal dominion (principality), and not only the city itself, is well exposed in the children of Mtskheta: Uplos, Odzrkhos and Javakhos - that are the same administrative units of: Javakheti, 
Odzrkhe with Klarjeti $^{7}$ and the Mtskheta-Uplistsikhe region managed from Mtskheta by the lord-upali from regions dependent on Mtskheta are referred to in the children of Mtskheta. This indicates the absence of the kings of Kartli and the ruling age of the Patrician $\left(6^{\text {th }}-8^{\text {th }}\right.$ centuries) of the country (Erismtavari in Georgian translation). The patrician age is also indicated by the fact that Kartlos' children, the same as the domains within Kartli are of equal status with regard to each other-brothers; Mtskhetos is just the elder brother of the peer. It's a known fact that Patrician Guaram, the father of Stepanos I, was ruling the country from Mtskheta City before his son Stepanos began to rule the country from Tbilisi in 591 .

The lower chronological boundary of the story cannot pass the middle of the $6^{\text {th }}$ century (disintegration of the Kingdom of Kartli and conversion to the system of Patriciate) and the upper chronological boundary would be the middle of the $8^{\text {th }}$ century, which is also indicated by the political-geographical nomenclature of the story. For the example, the name of one of the brothers of Kartlos, i.e., one of the political formations Egros-Egrisi is enough. This Western-Georgian kingdom/patriciate, which is known as Lazica in Byzantine sources, was named as Egrisi in Georgian sources (Egeri in Armenian sources). From the $2^{\text {nd }}$ half of the $8^{\text {th }}$ century in Georgian sources Egrisi was renamed as Abkhazeti (Abazgia in Byzantine sources). So if the work was created after the $2^{\text {nd }}$ half of the $8^{\text {th }}$ century, Kartlos' brother would be Abkhazos (Abazgos) and not Egros. The same can be said about Bardos, and Movakan (Mukan in Arabic sources).

Here we will try to separate in the text of The Life of the Fore-Patriarchs and Ancestors of the Georgian Kings the story of the seven brothers (which was supposed to be a small story of Karlos and his six brothers) from the materials taken from the Armenian historiography. In this case, we present a separated, reconstructed version of the text in parallel with the existing one. During our reconstruction, we only took out passages referring to Togarmah's son Haos, including his battle with Nebrot (Nimrod), which had been inserted in the text from Byzantine and Armenian historiography. The removed passages are shown in italicized bold letters in the main text given below. In the reconstructed text (the left column), the words in italics and bold are the ones that have been restored or changed. By "the main text", we mean The Old Georgian Chronicles that is referred to Leonti Mroveli $\left(2^{\text {nd }}\right.$ half of $11^{\text {th }}$ century), to differentiate it from the reconstructed text of The Ancient Georgian Chronicles that is referred to Juansher Juansheriani (60-70's of $6^{\text {th }}$ century. $)^{8}$ The missed space is identified by multiple dots. Missed are the parts of the text that have no importance for the research topic.

\footnotetext{
7 The fact that in case of Odzrkhe Saeristavo Klarjeti is included is obvious in the cities belonging to Odzrkhisi-Odzrkhe and Tukharisi. Tukharisi, as it is known, was the central fortress of Klarjeti.

${ }^{8}$ Concerning Juansher's identity and work, see Sanadze, 2001, pp. 122-127; Sanadze, 2016, pp. 381-386
} 


\section{The Genealogy of Kartlos and his Brothers-The Reconstruction of "Ancient Georgian Chronicles"}

First, we will say that Kartvels, Rans and Movakans, Hers and Leks, Megrels and Caucasians had one father, named Tar[Shi]Sh. This Tar[Shi]Sh was the grandson of Japheth the son of Noah.

Among his sons there were seven heroes who were strong and famous. Their names are: the first - Kartlos, the second - Bardos, the third - Movakan, the fourth Lek, the fifth - Heros, the sixth - Caucas, the seventh Egrisi; all the seven of them were heroes

And took them Tar[Shi]Sh to the north and divided the land among them, according to their merits:

Heros was given the country Heros built a town in the area between the junction of the two
The Genealogy of Kartlos and his Brothers-“Old Georgian Chronicles”

First, we will say that Somekhs (Armens - M. S.), Kartvels, Rans and Movakans, Hers and Leks, Megrels and Caucasians had one father, named Targamos (Togarmah). This Targamos was the son of Tarsh, and the grandson of Japheth the son of Noah.

And this Targamos was a hero. And after the confusionof languages, when the Towel of Babel was constructed and the languages divided and the peoples scattered around the world, he (Targamos) left with all his family and settled between two mountains inaccessible by humans-Ararat and Masis.

And his family was big and numerous, because he had many wives and sons and daughters and children and grandchildren of his sons and daughters, because he lived 600 years and the land of Ararat and Masis could no longer contain this amount of people. And the borders of the land allotted to him are as follows: The Sea of Gurgen in the east, the Sea of Ponto in the west, the Sea of Oreti in the south and the Caucasus Mountain in the north.

Among his sons there were eight heroes who were strong and famous. Their names are: the first Haos, the second - Kartlos, the third - Bardos, the fourth - Movakan, the fifth - Lek, the sixth - Heros, the seventh - Caucas, the eigth - Egrisi; all the eight of them were heroes.

And Haos was the greatest hero of them, because such a hero - strong in body and courageous - has never existed, neither before the Flood, nor after it.

And the country of Ararat and Masis could no longer contain such an amount of people. And Targamos divided his country and his people among these eight heroes: half of his family, and half and the best part of his land he gave to Haos, and divided the rest of the country to seven sons according to their "ardzang" (merit - M. S.).

And took them to the north and divided the land among them, according to their merits:

Heros was given the country Heros built a town in the area between the junction of the two Alazani

\footnotetext{
${ }^{9}$ We call the version of The Georgian Chronicles of Juansher "the ancient" to differentiate it from the edited and extended text of The Georgian Chronicles by Leonti that is usually called "old" in historiography. The new Georgian Chronicles is called the version of the text edited and extended under the commission of Vakhtang VI (years of reign: 1709-1723).
} 
Alazani Rivers ${ }^{10}$ and named it after himself - Hereti and that is why Hereti is called Hereti.

Egrisi was given the country a town and named it after himself.

Kartlos was given a country ........ The northern border of the country is Ghado and a small mountain .....

Bardos was given a country

Movakan was given the country

In the north of the Caucasus Tarshish did not inherit anything. Nobody lived there - in the country from the Caucasus to the Great River [of Khazars] flowing into the Daruband Sea. That is why he selected two heroes -Lek [and] Caucas out of many and gave Lek the country from the Daruband Sea to the River Lomeki and in the north to the Great River of Khazars; Caucas was given the country from the Lomeki, River to the end of the Caucasus in the west.

${ }^{10}$ Implying the Iori River and the Alazani River proper.
Rivers and named it after himself - Hereti and that is why Hereti is called Hereti. and this place is today called Khoranta.

Egrisi was given the country ....... And Egros built a town and named it after himself. Today this place is called Bedia

Kartlos was given a country ........ The northern border of the country is Ghado and a small mountain ..... which is now called Likhi.

Bardos was given a country

Movakan was given the country

In the north of the Caucasus Targamos did not inherit anything. Nobody lived there - in the country from the Caucasus to the Great River [of Khazars] flowing into the Daruband Sea. That is why he selected two heroes-Lek [and] Caucas out of many and gave Lek the country from the Daruband Sea to the River Lomeki and in the north to the Great River of Khazars; Caucas was given the country from the Lomeki River to the end of the Caucasus in the west.

Haos settled on the Land of his father Targamos and held the country in the following borders: in the north, as I wrote above, in the south-up to the Oreti Sea, in the east until the Sea of Gurgen and to the Ponto Sea in the west. Haos was a governer and Lord of these seven heroes and all they were obedient to Haos.

Language of all of them was Armenian. And all the eight heroes served Nebrot, who was the king of the world.

In several years Haos called the seven heroes and told them: Thanks to the lord we are large in number and by his help we will be able to workship only him and nobody else. The seven heroes accepted his decision and refused to give tribute to $\mathrm{Ne}$ brot.

Then Nebrot assembled his heroes and army and went against Targamosids. And Haos called upon the seven heroes, all Targamosids and other supporters from the west. Haos' army stopped near Masis.

Nebrot approached the country of Adarbadagan and sent sixty heroes and the strongest warriors to Targamosids.

The seven hero brothers of Haos met warriors sent by Nebrot. And Haos together with the 
Hence let us tell the story of Kartli and its people, until now. And as Tarshi divided his land among his people and his seven sons, initially, Kartlos came to the place where the Aragvi River joins the Mtkvari River and he went up the mountain the name of which was Armazi. Kartlos first built a fortress and a house upon it. He named the mountain after his own name - Kartli and the mountain was called this name until deity Armazi's idol was placed upon it. And because of that entire Kartli was called Kartli, from Khunani to the Speri Sea (the Black Sea, M. S.). Afterwards, Kartlos built the Orbi Fortress. He also built the Mtueri Fortress. Kartlos lived many years and left many descendants. strongest army stood in the back. There was a severe battle among them with dust like a could, swords lightening like a lightning in the sky and the noise was like a thunder; arrows and stones were shot like hail and blood flew in torrents; huge number of warriors died from both parties.

Haos stood in back of his army and supported them and gave hope by calling in thunder voice. Targamosids defeated Nebrot's sixty heroes and his army. And Targamoss seven sons - Kartlos, Bardos, Movakan, Heros, Lek, Caucas, Egris, stayed.

And as Nebrot heard this, he got furious and advanced towards them with all his forces. As for Haos, his troops were not as numerous as those of Nebrot. So, he fortified himself in a rocky place in Masis. Nebrot approached him from beneath. And he was armored with iron and copper from head to foot. And he ascended a hill to address Haos and demand his obedience, as he would rejoice in his yield.

And Haos called upon his heroes: "Uphold me and I will approach Nebrot". And he departed and met Nebrot head-on nearby. And he threw an arrow which hit Nebrot in the chest, in his copper breastplate and went straight through it and out of his back. Then Nebrot fell to the ground and his camp escaped and the offspring of Targamos got free. And then Haos made himself king of his brothers and other peoples settled near his country. And these seven brothers left for their countries and were submitted to Haos. Up to this point, we have related the story of the eight brothers.

Hence let us tell the story of Kartli and its people, until now. And as Targamos divided his land among his people and his eight sons, initially, Kartlos came to the place where the Aragvi River joins the Mtkvari River and he went up the mountain the name of which was Armazi. Kartlos first built a fortress and a house upon it. He named the mountain after his own name - Kartli and the mountain was called this name until deity Armazi's idol was placed upon it. And because of that entire Kartli was called Kartli, from Khunani to the Speri Sea (the Black Sea, M. S.). Afterwards, Kartlos built the Orbi Fortress, which is now called Samshvilde. He also built the Mtueri Fortress that is now called Khunani. Kartlos lived many years and left many descendants. 
Among his sons there were five heroes: the first one was Mtskhetos, the second Gardabos, the third Kakhos, the fourth Kukhos, and the fifth Gachios. All of them were heroes, yet Mtskhetos was the greatest hero among them.

Kartlos died and was buried on Kartli Mountain called Armazi. After his death Kartlos' wife built the Mother Fortress (the Main Fortress) and built Bostan-town. She divided the country among her five hero-sons:

Gardabos was given Khunani..........

Gachios was given the Orbi Fortress ..... and Gachios built a town Gachiani, which is called Sanadiro-Kalaki (meaning "town for hunting").

Kukhos was given Bostan-Town, and ......

Kakhos was given a part of the country between the Caucasus and Kakheti mountains

As for Mtskhetos, who was the greatest hero among his brothers, he remained at his father's place...... He was the ruler and the lord among the four brothers and they were obedient to him.

This is how the country was divided among Kartlos' sons by their mother after Kartlos' death. The son of Kartlos lived many years and long times and Kartlos' descendants increased in number. And the descendants of the descendants multiplied too. Among Mtskhetos' sons there were three famous heroes whose names were: the first one - Uplos, the next one Odzrkhos and the third one - Javakhos. Mtskhetos divided his country among them and all their people.

Odzrkhos was given a territory from.......

Odzrkhos built two fortress-towns: Odzrkhe and Tukharisi.

Javakhos was given a territory from...

Javakhos built two fortresses: Tsunda and the town of Artaani that is called the Town of Kajs .

Uplos (Lord, M. S.) remained in their father's Mtskhetos country-Mtskheta.

Uplos built Uplis-tsikhe (the fortress of the Lord, M. S.) and Kaspi. Uplos named the territory from the Aragvi and Armazi to Tasis-Kari as Zena Soplisa (Apper Country - M. S.).
Among his sons there were five heroes: the first one was Mtskhetos, the second Gardabos, the third Kakhos, the fourth Kukhos, and the fifth Gachios. All of them were heroes, yet Mtskhetos was the greatest hero among them.

Kartlos died and was buried on Kartli Mountain called Armazi. After his death Kartlos' wife built the Mother Fortress (the Main Fortress) and built Bostan-town that is called Rustavi today. She divided the country among her five hero-sons:

Gardabos was given Khunani.

Gachios was given the Orbi Fortress ..... and Gachios built a town Gachiani, which was called Sanadiro-Kalaki (meaning "town for hunting").

Kukhos was given Bostan-Town, which is now called Rustavi and....

Kakhos was given a part of the country between the Caucasus and Kakheti mountains ....

As for Mtskhetos, who was the greatest hero among his brothers, he remained at his father's place that is now called Armazi..... He was the ruler and the lord among the four brothers and they were obedient to him.

This is how the country was divided among Kartlos' sons by their mother after Kartlos' death. The son of Kartlos lived many years and long times and Kartlos' descendants increased in number. And the descendants of the descendants multiplied too. Among Mtskhetos' sons there were three famous heroes whose names were: the first one - Uplos, the next one Odzrkhos and the third one - Javakhos. Mtskhetos divided his country among them and all their people.

Odzrkhos was given a territory from......

Odzrkhos built two fortress-towns: Odzrkhe and Tukharisi.

Javakhos was given a territory from...

Javakhos built two fortresses: Tsunda and the town of Artaani, which at that time was called the Town of Kajs and now it is called Huri.

Uplos (Lord, M. S.) remained in their father's Mtskhetos country-Mtskheta.

Uplos built Uplis-tsikhe (the fortress of the Lord, M. S.) and Kaspi. Uplos named the territory from the Aragvi and Armazi to Tasis-Kari as Zena Soplisa, that is now called Shida Kartli. 
After the death of Mtskhetos - the son of Kartlos envy emerged among Kartlos' descendants; they started fighting and killing one another. They did not obey Uplos, nor did they recognize him as the Lord. Although he was left on the throne of Kartlos and was given power by his father to be Lord of Kartlosids.

And so peaceful periods were followed by battles again. And this situation continued and neither of them was the most outstanding and renowned among them. But there emerged a superior in each place.

As for the person who was in Mtskheta, he was neither superior over others, nor was he called King or Eristavi, but he was called Mamsakhlisi. He made peace and justice among Kartlosids.

As the town of Mtskheta was the most famous among other towns, it was announced as the capital of the country. At that time, people forgot about the Lord, their creator and started to worship the sun, moon, five stars and Kartlos' grave was the firmest and most significant sacrament".
And up to the death of Mtskhetos, all descendant s of Targamos loved one another and they were afraid of Nebrotand they thought that Nebrotids could take revenge on them because of Nebrot's killing and that's why, because of fear of Neberotids, they fortified their fortresses and towns.

After the death of Mtskhetos - the son of Kartlos envy emerged among Kartlos' descendants; they started fighting and killing one another. They did not obey Uplos, nor did they recognize him as the Lord. Although he was left on the throne of Kartlos and was given power by his father to be Lord of Kartlosids.

And so peaceful periods were followed by battles again. And this situation continued and neither of them was the most outstanding and renowned among them. But there emerged a superior in each place.

As for the person who was in Mtskheta, he was neither superior over others, nor was he called King or Eristavi, but he was called Mamsakhlisi. He made peace and justice among Kartlosids.

As the town of Mtskheta was the most famous among other towns, it was announced as the capital of the country. At that time, people forgot about the Lord, their creator and started to worship the sun, moon, five stars and Kartlos' grave was the firmest and most significant sacrament".

The main objective of the story of Kartlos and his six brothers was to strengthen the assumption of the origin of Kartli and the Caucasian peoples through a Biblical approach and at the same time represent Kartli (Iberia) as an elder brother (the first among equal ones) in a leading position among Caucasian political units of the author's period.

In the same period $\left(5^{\text {th }}-7^{\text {th }}\right.$ centuries), under Byzantine influence, the story of Togarmah's and his family's (Hayk, Armen, Khoro, Manavaz...) settlement in South Caucasia, his battle with Bell (in Georgian version - Nebrot) and his defeat evolved in Armenian historiography. Later, Leonti Mroveli by the end of the 11th century or an unknown Georgian chronicler in the $1^{\text {st }}$ half of the $12^{\text {th }}$ century compiled these stories, added some other information to them and created a new extended and compiled version of The Life of the Fore-Patriarchs and Ancestors of the Georgian Kings serving as an introductory part of The Georgian Chronicles. At the same time the whole text of The Georgian Chronicles was edited in compliance with the contemporary views of that period.

Let's look at all three Genealogical schemes now: Biblical-Byzantine, proto-Georgian and Armenian: 


\section{Biblical:}

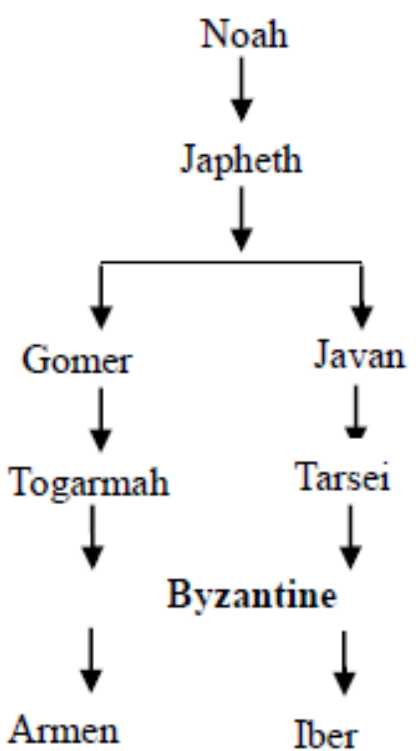

Proto-Georgian

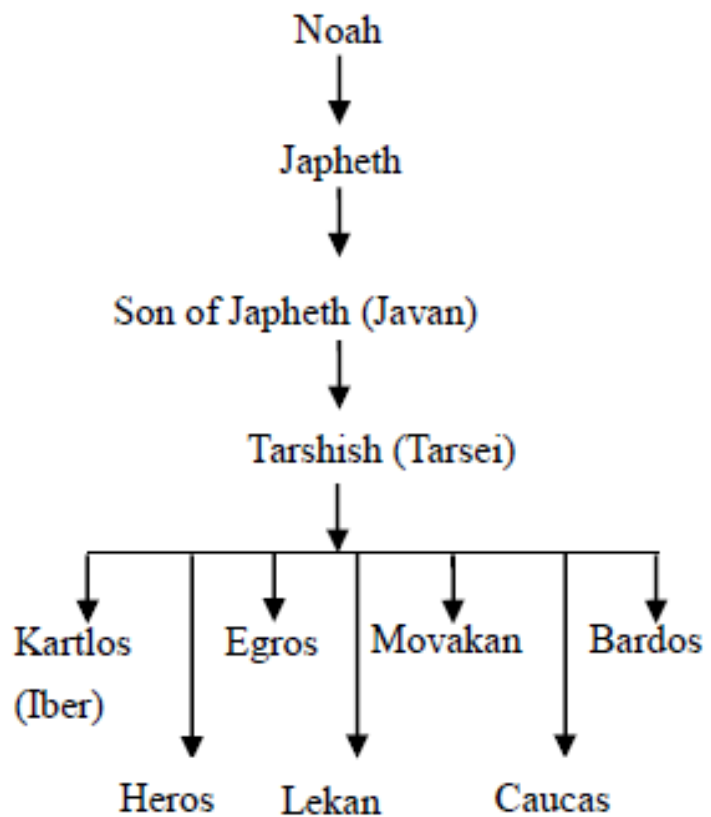

Armenian:

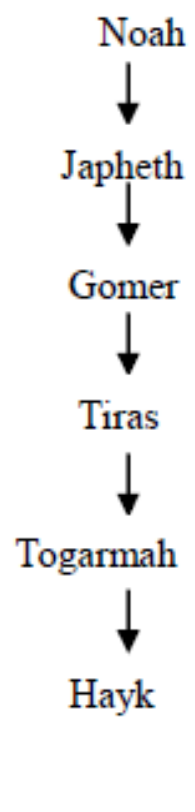

Presumably, developing the synthesized version of Georgian and Armenian genealogic schemes by the Georgian chronicler who edited and extended The Life of the Fore-Patriarchs and Ancestors of the Georgian Kings, would have been a difficult task. The difficulties were associated with his aim, which would be the alignment of the Georgian (Kartlos and his six brothers) genealogic scheme with the Armenian one. The necessity to align the schemes proceeded from the reality in which a large amount of Armenians became citizens of the Georgian kingdom. It has to be mentioned that this idea seems to face a barrier that is impossible to overcome: as it becomes clear from Movses Kaghankatvatsi, Georgians and Armenians had a good understanding of their origin (Georgians from Tarshish and Armenians from Togarmah) coming from prominent Byzantine writings and evidenced by it. Thus, the Georgian chronicler could not have ignored this condition. The integration of Georgian and Armenian genealogic schemes would only be possible by labelling Tarshish (Tarsei) and Togarmah as father and son, and preserving the names Georgians' Tarsei (Tarshish) and Armenians' Togarmah at the same time. The fact that this synthesis of genealogical schemes was made by the Georgian chronicler is evident from the fact that Tarshish (Tarsei), Georgians' ethnarch, became the father of Armenians' ethnarch Togarmah, not vice versa.

At the same time, Haos was accepted to be Togarmah's son and consequently the "seven brothers" led by Kartlos had to follow Haos after their "father" Tarshish became Togarmah's "father". 


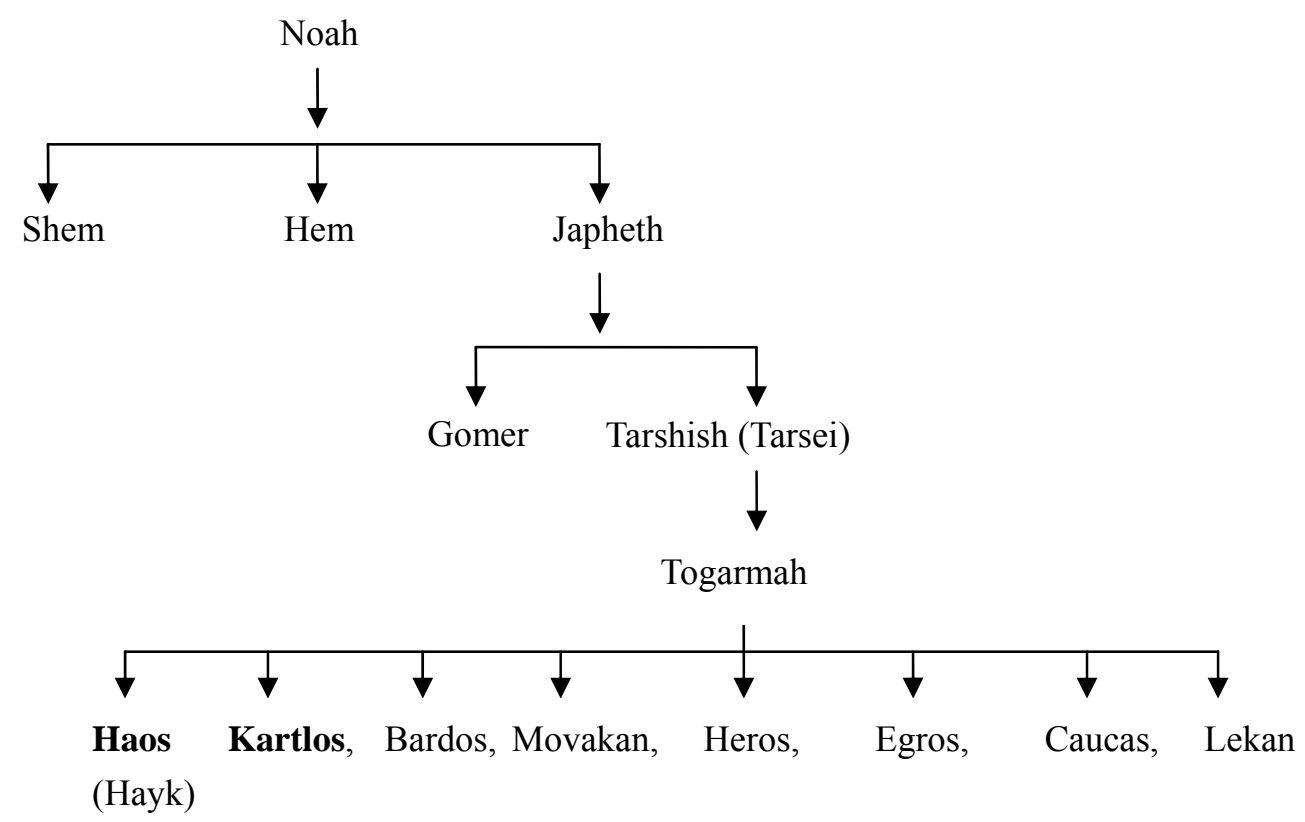

Thus, as a result of synthesizing two (Georgian and Armenian) genealogical schemes, Georgians (Kartlos) gave superiority to Haos//Hayk (elder brother). But the concession of this leading position has a big geo-political goal. Actually, the Georgian society was not losing anything by this: when the schemes were synthesized, there were no Armenian political units, so nobody would claim to be older than the "younger brother"; even more, Kartlos, as a younger brother, became the only legal successor of Armenian lands. In fact, according to G. Japaridze, Arab authors mention that Georgians stated that they are the only legal heirs of Armenian territories, because they are the "successor brother" of Armens (Japaridze, 2009, p. 201; Sanadze \& Arakhamia, 2012, p. 270).

\section{Conclusion}

Finally, it should be concluded that the first, introductory story of The Georgian Chronicles-The Life of the Fore-Patriarchs and Ancestors of the Georgian Kings - is not devoid of historical value, as it was widely accepted before, but it is quite an interesting work from many perspectives. The textual and content analysis of the story has made it possible to: (1) identify an ancient Georgian work of a genealogical and geopolitical nature, which has been preserved only thanks to The Life of the Fore-Patriarchs and Ancestors of the Georgian Kings; (2) single out the plot of the fight of Haos against Nebrot (and not Bell) taken from Armenian historiography, which has not been preserved in the given form in the extant works of old Armenian historians; (3) follow the development of genealogical schemes and genealogical thought both in old Georgian and old Armenian societies; (4) bring to light the goals and aspirations that conditioned the creation of the introductory story of The Georgian Chronicles on the verge of the $11^{\text {th }}-12^{\text {th }}$ cc.

\section{References}

Abdaladze, A. (1982). The Georgian Chronicles and Georgia-Armenian relations. Tbilisi: Metsniereba.

George Syncellus. (1941). Georgica-Information of the Byzantine writers about Georgia (Vol. IV, Section I). Tbilisi: Georgian Scientific Academy Publishing - Metsniereba. 
Japaridze, G. (2009). Views of Arabs of the Middle Ages about the origin of Georgians-Collection: Scientific paradigms. Tbilisi: Meridiani.

Kekelidze. K. (1955). Sketches, III. Tbilisi: Tbilisi State University Press.

Liber Generationis. (1961). Georgika, Information of the Byzantine writers about Georgia (Vol. I). Tbilisi: Georgian Scientific Academy Publishing - Metsniereba.

Movses Kaghankatvatsi. (1985). The history of the country of Alvans (Translation from old Armenian, introduction, comments and index by Liana Davlianidze-Tatishvili). Tbilisi: Georgian Scientific Academy Publishing - Metsniereba .

Movses Khorenatsi. (1984). History of Armenia (Translation from Old Armenian, introduction and commentaries by Aleksandre Abdaladze). Tbilisi: Georgian Scientific Academy Publishing - Metsniereba .

Sanadze, M. (2001). Juansher Juansheriani and the period of his life. Tbilisi State University Works. A Series of History - 338. Tbilisi: Tbilisis State University Press.

Sanadze, M., \& Arakhamia, G. (2012). The issue of Biblical descent of Georgians and Armenians. IV Annual Conference in Humanities of the University Of Georgia (published materials). Tbilisi: The University of Georgia Press.

Sanadze, M. (2016). Chronology of Georgian Kings and Patricians of the ancient period and the early Middle Ages (from Pharnavaz to Ashot Curopalates). Tbilisi: The University of Georgia Press.

The Georgian Chronicles. (1955). (Text established according to all basic manuscripts by Kaukhchishvili, Vol. I). Tbilisi: Tbilisi State University Press. 